\title{
Pakistan's External Trade: Does Exchange Rate Misalignment Matter for Pakistan?
}

\author{
M. Ashraf Janjua*
}

\begin{abstract}
This paper is primarily aimed at assessing the significance of the exchange rate on Pakistan's foreign trade. It estimates the Equilibrium Real Effective Exchange Rate (ERER) and exchange rate misalignment for Pakistan using annual data from FY78 to FY06. The Engle Granger cointegration technique is used for the estimation of ERER depending upon various macroeconomic fundamentals as recommended by Edwards (1994). The results of the study are also used for the forecasting of ERER and misalignment up to the year 2010. The results of the study reveal that ERER is determined by variables such as: a) terms of trade, b) trade openness, c) net capital inflows, d) relative productivity differential, e) government consumption, and fl workers' remittances.

The error correction term points to the gradual convergence of the real exchange rate towards the long-run equilibrium level which suggests that the prevailing Pak Rupee exchange rate has not deviated from the ERER and captures economic fundamental trends. Moreover, Pakistan's foreign trade would depend significantly upon the state of economic fundamentals in the future. Improved economic fundamentals are likely to support trade besides paving the way for enhanced inflows of capital and financial receipts.
\end{abstract}

\section{Introduction}

The economic literature recognizes that exchange rate policy influences various parts of the balance of payments. It affects the balance of trade of a country mainly through improving international competitiveness which affects the supply and demand for exports and imports (i.e. the elasticities of supply and demand for exports and imports). In fact, exchange

\footnotetext{
* Dean, College of Business Management, Karachi, and Former Deputy Governor, State Bank of Pakistan.
} 
rate policy affects the international competitiveness of domestic products as: a) changes in the cost of production may raise the domestic price level; b) changes in domestic price may also affect production costs if changes in wages are in line with the changes in cost of living when imports become more expensive with depreciation; and c) if a large country depreciates its currency, the exports from small countries to the concerned country may be reduced. Keeping in view its significance, every government needs an exchange rate policy and has to make a strategic choice between a fixed exchange rate regime, a flexible exchange rate regime, or one of various inbetween options. Each policy has its own advantages and disadvantages, and each country's circumstances are different. Although many countries have pegged their exchange rates with hard currencies, there is a clear trend towards greater flexibility in exchange rate policy. Moreover, a central bank that is independent of the government is committed to maintaining low inflation and full employment does not finance budget deficits and often prefers a flexible exchange rate.

Historically, Pakistan pursued a policy of export-led growth, with the objective of achieving viability in her balance of payments. With a view to achieving this objective, the country had to adopt various exchange rate regimes at different times. A fixed exchange rate regime was followed from 1947 to $7^{\text {th }}$ January, 1982. During the early 1980s, the dollar started appreciating in terms of the major currencies and as the Rupee was linked to the U.S. dollar, this affected the competitiveness of Pakistani products in international markets. Thus, with a view to maintaining the competitiveness of exports and thereby to bring a sustainable balance between the country's current receipts and current payments, it was decided to adopt the managed floating exchange rate system w.e.f. $8^{\text {th }}$ January, 1982 . Under this system the value of the Pak-Rupee was reviewed daily with reference to a trade weighted basket of currencies of the country's major trading partners/competitors. Necessary adjustments in the value of the Pak-Rupee were made as and when circumstances indicated a need for such an adjustment, keeping in view the relative changes in exchange rates and the prices of the country's major trading partners/competitors as well as major macro-economic indicators of Pakistan. The managed float continued to operate successfully till 21 st July, 1998. In the wake of economic sanctions by major donors and the restraining stance adopted by multilateral financial institutions as a reaction to the nuclear tests on May 28, 1998, Pakistan had to take a number of measures to face the challenge. As a part of this strategy, the State Bank of Pakistan (SBP) introduced a New Exchange Rate Mechanism (NERM) on $22^{\text {nd }}$ July, 1998, replacing the managed-floatingexchange-rate system. The underlying philosophy of the dual exchange rate was to pass on the advantages of devaluation to exporters, expatriate workers 
wishing to remit money to Pakistan and to compress non-essential imports. It was also intended to contain the cost of devaluation in terms of containing price increases of essential imports and repayments of the external debt thereby limiting the impact of inflation and the overall fiscal deficit of the government. The adoption of NERM was tantamount to a multiple currency practice. The multiple exchange rate system discriminated among different exporters and importers and led to a misallocation of resources with an adverse impact on output and growth. Further, under the I.M.F's Articles of Agreement, a member is not allowed, except temporarily, to engage in multiple currency practice. The two-tier exchange rate system was replaced with a market- based unified exchange rate system w. e. f. May 19, 1999. Under the unified exchange rate system, a floating inter-bank rate was applied to all foreign exchange receipts and payments both in the public and private sectors. However, the State Bank could intervene in the market for the sale and purchase of foreign exchange on its own account at rates and timing of its choice. On $20^{\text {th }}$ July 2000, Pakistan set the Pak rupee on a free float.

Since the free float of the Pak rupee, monetary policy has played a dominant role in stabilizing the exchange rate in Pakistan. Significant ups and down in forex rates are now being monitored through effective instruments of monetary policy. Similarly, whenever speculative activities are observed in the market, they are tackled with proactive monetary policy measures of the State Bank. The Bank uses the instrument of the discount rate to control undue pressure on the exchange rate while Cash Reserve Requirements (CRR) or mopping up of excessive liquidity through purchases from the kerb market, to curb speculative activities in the forex market. The recent level of the nominal exchange rate appears to be controversial from the monetary policy angle. Although the SBP considers the current level of the exchange rate suitable for foreign trade, the IMF and other institutions have shown their concern recently over its suitability which is based on continuous deterioration of Pakistan's external trade, particularly the current account.

One viewpoint is that the appreciation of the Pak rupee is the result of a host of other factors, thus it is difficult to assess the creditability of the recent level of the nominal exchange rate from a monetary point of view. The reason is that monetary policy simply helped exchange rate stabilization at a specific level. It is, therefore, difficult to say that the recent level of the exchange rate is close to the equilibrium level.

The prime objective of the current study is to evaluate the suitability of existing exchange rate policy for Pakistan's external trade. It 
will particularly pinpoint the magnitude if the exchange rate has deviated significantly from its equilibrium level. For this purpose, the paper is organized in the following way. The second section is about the history of exchange rate regimes and its significance for Pakistan's external trade. The third section discusses the methodology used for assessing the deviation of the exchange rate from its equilibrium level. The fourth section pertains to concluding remarks.

\section{Exchange Rate Regimes and Pakistan Foreign Trade}

Pakistan pursued different exchange rate regimes in its history spreading over 60 years. Initially, the Pak rupee was pegged to the Pound Sterling. The Pak rupee was then pegged to the US dollar in 1971 and the new exchange rate parity was fixed at Rs. 4.76 per US \$. After the separation of erstwhile East Pakistan (now Bangladesh) in December 1971, Pakistan had problems in absorbing the surplus products which earlier used to be sent to former East Pakistan. Large amounts of raw cotton piled up during fiscal year 1971/72. Since its introduction on $15^{\text {th }}$ January 1959, the Export Bonus Scheme (EBS) had become increasingly complex with all the adverse consequences of multiple exchange rates for resource allocation. Also, Pakistan experienced a high rate of inflation during this period. These events convinced policy makers to rationalize the exchange rate through adjustment. As a result, the Rupee was depreciated on $11^{\text {th }}$ May, 1972 and the new exchange rate was set at Rs. 11.00 per US Dollar.

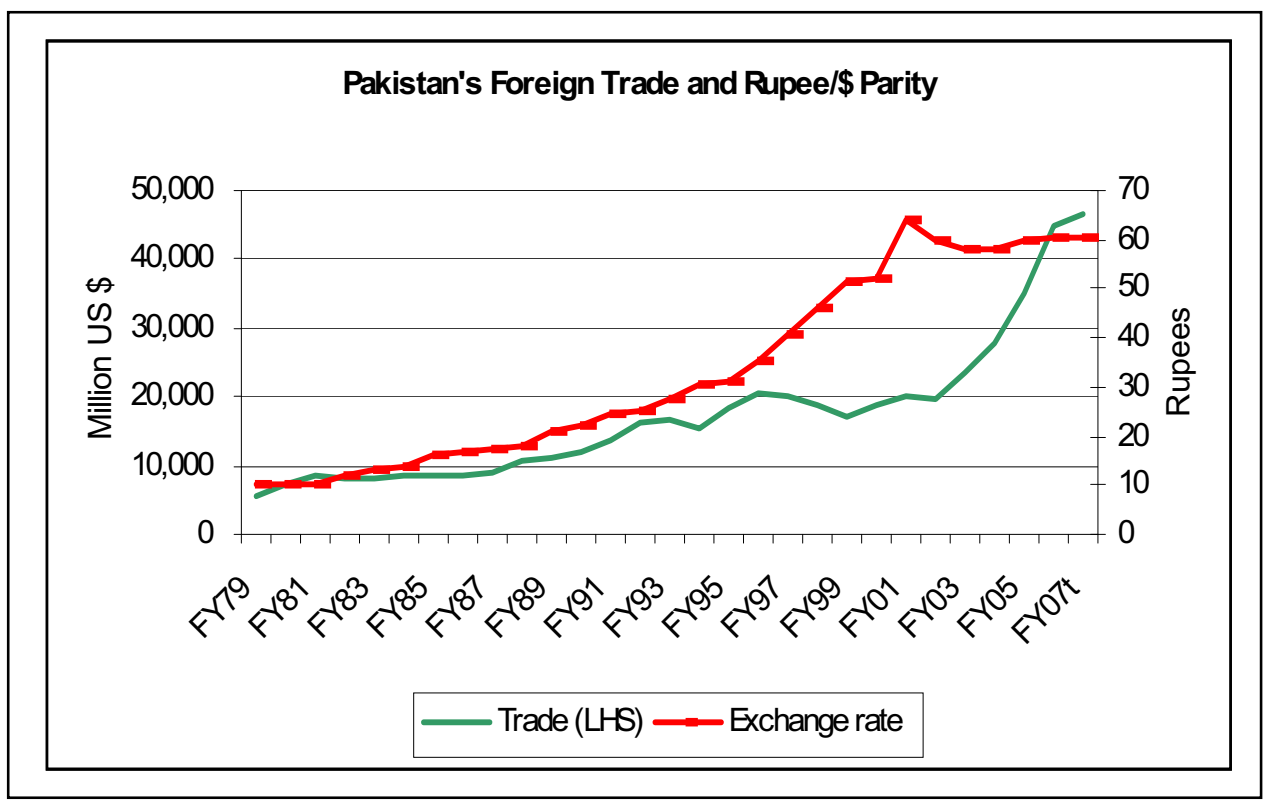


The new exchange rate was viewed by some people as excessive devaluation of the Rupee ${ }^{39}$. However, when the US\$ was devalued by $10 \%$ in February 1973, the Pak Rupee, being linked with US\$, automatically appreciated by $10 \%$ and the new exchange rate was the Pak Rupee 9.90 per US dollar. This exchange rate continued till $8^{\text {th }}$ January 1982, when the fixed exchange rate was discarded, and the State Bank of Pakistan adopted a managed float based on a basket of 16 currencies of Pakistan's trade partners.

Following the worldwide trend of deregulation of economies and exchange rates, Pakistan opted out of the fixed exchange rate regime and floated the value of the rupee against a basket of sixteen currencies under a managed exchange rate regime on $8^{\text {th }}$ January 1982 . As a result, the value of the rupee depreciated quite significantly after the adoption of the managed floating regime. During the 1990s, the value of the rupee was generally set in line with the inflation differential. In other words, the rupee had to be devalued to offset the adverse effect of domestic inflation on the real exchange rate. For the last decade, however, exchange rate depreciation has been undertaken more as a desperate attempt to control the rising Current Account Deficit (CAD) than to follow the Purchasing Power Parity (PPP) rule. The cumulative current account deficit during the period 1992/98 stood at about US\$23-30 billion which was financed by the entire amount of US $\$ 11.0$ billion of foreign currency deposits besides government's additional external borrowings. Accumulation of large shortterm liabilities in the absence of an equal rise in foreign exchange reserves was bound to lead to a crisis in a period of economic or political uncertainties. The economic crisis occurred when Pakistan exploded the nuclear bomb on May 28, 1998.

During the fixed exchange rate regime from FY73-82, the actual Real Effective Exchange Rate (REER) moved in tandem with the price differential and the movement of the US Dollar vis-à-vis major currencies. The Rupee regained competitiveness in real terms during 1976-79, because of the continued lower inflation differential and US Dollar depreciation visà-vis major currencies. During the early 1980s, the REER appreciated substantially due to the appreciation of the US Dollar against major currencies and higher domestic inflation as compared to its trading partners. Keeping in view this sharp appreciation, Pakistan adopted the managed floating exchange rate system on January 8,1982 . The period thereafter was

${ }^{39}$ For details of discussion among the policy makers which led to new exchange rate, please see Janjua, "The History of State Bank of Pakistan, Volume-III, (1977-88)," pp $409-413$. 
characterized by more frequent and small adjustments in the Rupee against the US Dollar, keeping in view the relative changes in exchange rates and the prices of the country's major trading partners/competitors as well as the various macroeconomic indicators of Pakistan.

With the transformation of the economy from a semi-closed to a more open or market-oriented economy in the beginning of the 1990s, the exchange rate saw a much larger devaluation in nominal terms, which was just offset by a higher level of inflation in Pakistan as compared to its trading partners. The imposition of economic sanctions following the nuclear tests in May 1998 created a crisis-like situation and the State Bank of Pakistan introduced a number of measures including the implementation of a two-tier exchange rate system ${ }^{40}$ among others, from $22^{\text {nd }}$ July 1998 , to steer the economy out of the crisis. On May 19, 1999, the SBP moved from multiple exchange rates to the dirty float by defending the exchange rate within a narrow band up to $20^{\text {th }}$ July 2000 by channeling the foreign exchange from the kerb market to the inter-bank market through kerb purchases. In July 2000, the SBP moved away from the managed exchange rate to a floating exchange rate regime.

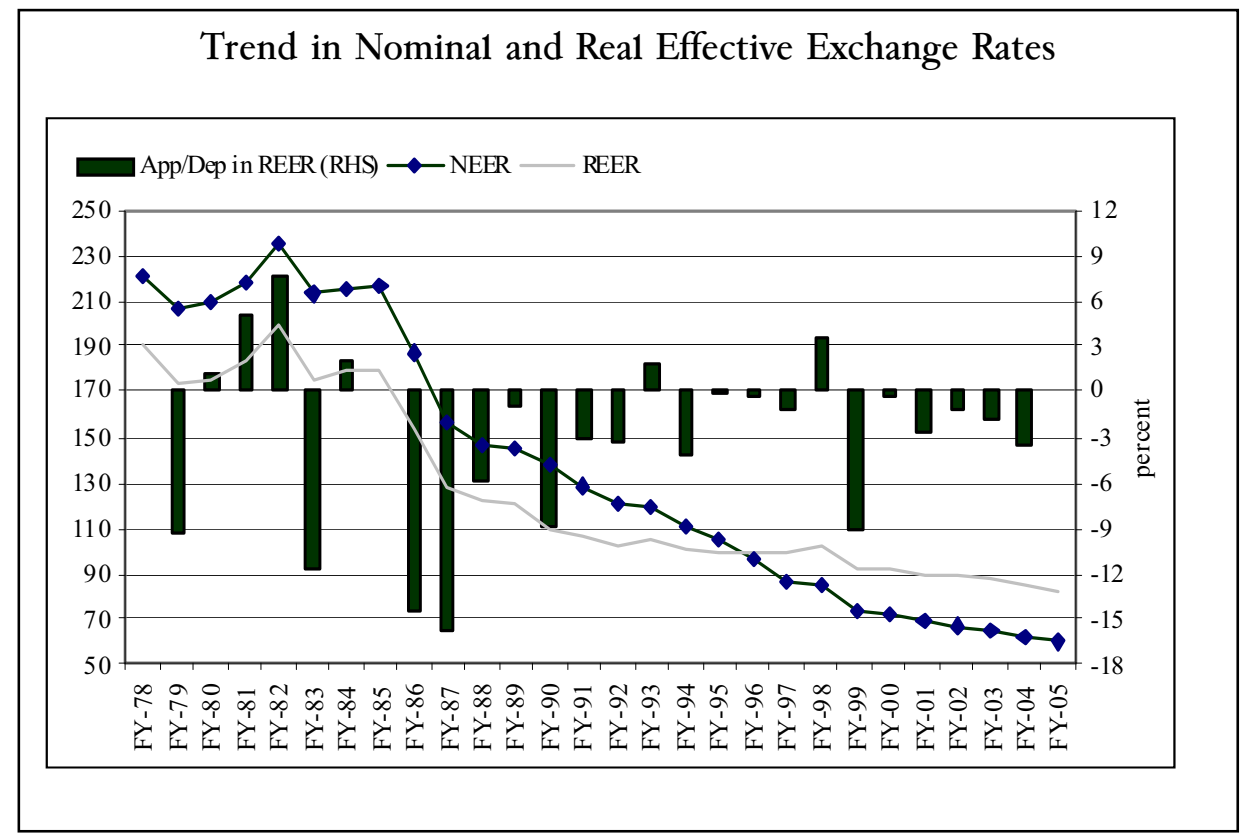

\footnotetext{
${ }^{40}$ The new mechanism was based on: a) official exchange rate, b) floating inter-bank exchange rate, and c) composite rate.
} 


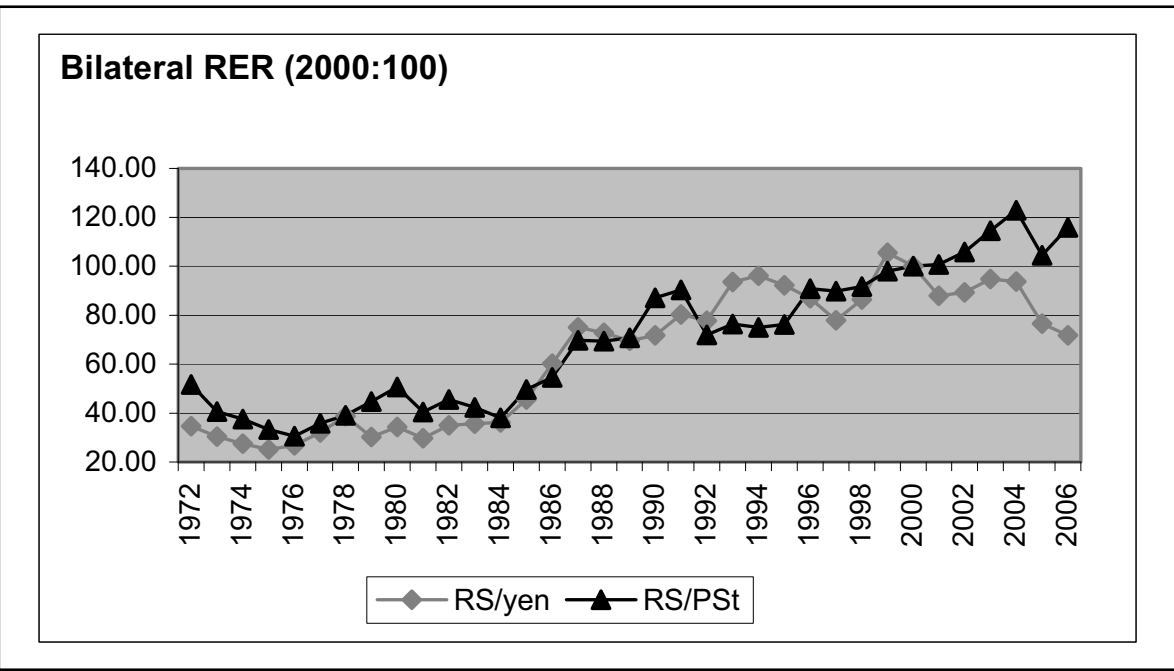

Initially, the rupee dollar parity witnessed a sharp nominal depreciation of $18.5 \%$ during Fiscal Year 2001, which shows the market correction of the cumulative overvaluation that took place during Fiscal Year 1999 and Fiscal Year 2000. In the new exchange rate regime, monetary instruments act as a nominal anchor to curb the anticipated high volatility of the exchange rate. This, coupled with the build-up of forex reserves, led to stability in the nominal exchange rate after the sharp depreciation in Fiscal Year 2001. The substantial surge in workers' remittances in the interbank market following the international crackdown on informal channels after the September 11, 2001 incident reversed the downward trend in the exchange rate. The excess liquidity in the foreign exchange market, following the post September 11, 2001 surge in workers' remittances in the formal banking channel, induced the SBP to purchase US\$ 8.2 billion from October 2001 to March 2004 to preserve the competitiveness of exports from abrupt exchange rate appreciation. The increased demand of foreign exchange from importers dried up excess liquidity in the inter-bank market, which not only prompted the SBP to scale down its purchases from the inter-bank market; SBP also had to start providing market support by financing lumpy oil payments. Interestingly, in real terms, the Rupee continued to maintain the compositeness due to the fact that the basket of currencies appreciated against the Dollar more than the Rupee and relatively higher inflation compared to that of trading partners. 


\begin{tabular}{|c|c|c|}
\hline \multicolumn{3}{|c|}{ Exchange Rate } \\
\hline Exchange Rate Regime & $\begin{array}{c}\text { (Pak Rupee per US } \\
\text { Dollar) }\end{array}$ & $\begin{array}{c}\text { App(+)/ } \\
\text { Dep(-) }\end{array}$ \\
\hline Prior to August, 1955 & 3.31 & \\
\hline $8 / 1 / 1955 \quad$ (i) Fixed Exchange Rate & 4.76 & -30.46 \\
\hline $5 / 11 / 1972$ from $14-8-1947$ to $07-01-1982$ & 11 & -56.73 \\
\hline $13-F e b-73$ & 9.9 & 11.11 \\
\hline 8-Jan-82 & 10.1 & -1.98 \\
\hline 1981-82 & 10.5535 & -4.30 \\
\hline $1982-83$ & 12.7063 & -16.94 \\
\hline 1983-84 & 13.4838 & -5.77 \\
\hline $1984-85$ & 15.1668 & -11.10 \\
\hline $1985-86$ & 16.1391 & -6.02 \\
\hline 1986-87 & 17.1795 & -6.06 \\
\hline 1987-88 & 17.5994 & -2.39 \\
\hline $1988-89$ & 19.2154 & -8.41 \\
\hline 1989-90 (ii) Managed Float & 21.4453 & -10.40 \\
\hline 1990-91 from 8th Jan. 1982 to 21st July 1998 & 22.4228 & -4.36 \\
\hline $1991-92$ & 24.8441 & -9.75 \\
\hline 1992-93 & 25.9598 & -4.30 \\
\hline 1993-94 & 30.1638 & -13.94 \\
\hline 1994-95 & 30.8507 & -2.23 \\
\hline $1995-96$ & 33.5684 & -8.10 \\
\hline 1996-97 & 38.9936 & -13.91 \\
\hline $1997-98$ & 43.1958 & -9.73 \\
\hline $\begin{array}{l}\text { 1998-99 - (iii) Two tier Exchange Rate System } \\
\text { (Multiple Exchang Rate) } \\
\text { from 22nd July } 1998 \text { to 18th May } 1999\end{array}$ & 50.0546 & -13.70 \\
\hline $\begin{array}{l}\text { 1999-00 - (iv) Dirty Float: SBP defending the } \\
\text { exchange rate within a narrow band } \\
\text { from 19th May } 99 \text { to 20th Ju1 2000 }\end{array}$ & 51.7709 & -3.32 \\
\hline 2000-01 (v)from Managed Float to Floating & 58.4378 & -11.41 \\
\hline 2001-02 Exchange Rate regime & 61.42580 & -4.86 \\
\hline 2002-03 Since July 20, 2000 & 58.49950 & 5.00 \\
\hline $2003-04$ & 57.57450 & 1.61 \\
\hline 2004-05 & 59.35760 & -3.00 \\
\hline $2005-06$ & 59.85660 & -0.83 \\
\hline
\end{tabular}


1) The two-tier exchange rate system was introduced on July 22, 1998. The new mechanism was based on: a) official exchange rate, b) floating inter-bank exchange rate, and c) composite rate.

2) The exchange rate system was unified on May 19, 1999.

Since the free float of the rupee, the monetary policy has played a dominant role in stabilizing the exchange rate in Pakistan. Significant ups and downs in forex rates are now being monitored through effective instruments of monetary policy. Similarly, whenever speculative activities are observed in the market, they are tackled with proactive monetary policy measures taken by the State Bank. The Bank uses the instrument of discount rate to control undue pressure on the exchange rate while the CRR or mopping up of excessive liquidity through purchases from the kerb market are used to curb speculative activities in the forex market. According to the SBP, the following considerations are generally taken into account while looking at the level of the exchange rate from the monetary policy side:

1. The existing level of the exchange rate has helped improve the build-up of forex reserves. There is a continuous increase in forex reserves, which is also a positive sign for the economic stability of the country.

2. The existing exchange rate level has sufficiently discouraged speculative activities in the forex market.

3. The rate has also helped discourage inflows of foreign remittances from illegitimate channels. Now there are less incentives for remitters to transmit their money through Hundi or other illegal channels.

4. The rate has helped strengthen the role of the inter-bank market. The two forex markets are expected to integrate if the existing rate prevails for a longer period.

5. The existing level of the exchange rate has smaller pass-through, which is evident from the lower inflation rate.

6. The rate is also providing an incentive to capital inflows. Some positive developments are also witnessed on the private foreign investment front. 
Like other economies, the September 11, 2001, incident had significant consequences for the Pakistani economy. The process of appreciation of Rupee-Dollar parity not only started but quickened primarily during the month of October 2001 in the wake of increasing capital inflows from the international community and donor agencies and easing of quota restrictions imposed on some Pakistani exportables to the Euro zone and the United States. The strengthening of the Rupee resulted from a variety of factors, these included the lifting of US sanctions, easing of quota restrictions by the European community, rescheduling of external debt, a positive response by the IMF in terms of approval of credit lines, an increase in foreign exchange reserves and diversion of investment funds from the currency market to the stock market.

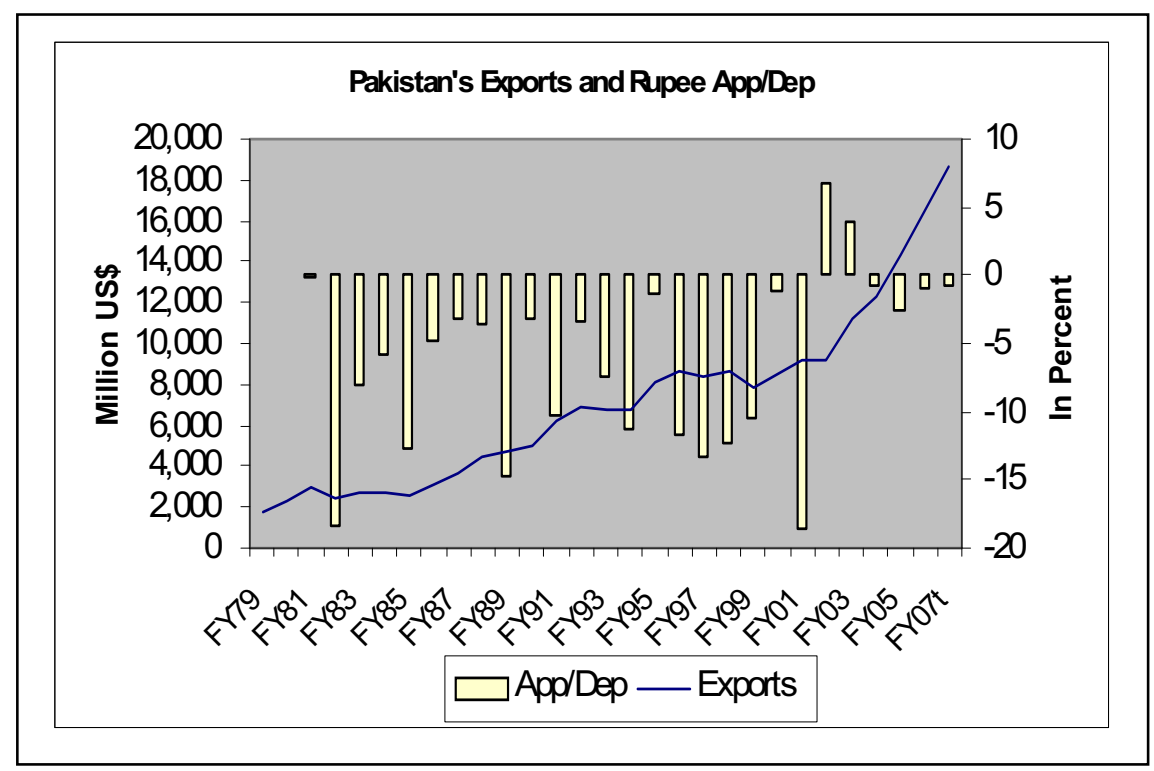

As regards Pakistan's exports, it may be noted that Pakistan's export structure has a very narrow base, both in terms of products and markets, and most of the exportable items are of low value addition. The composition of exports mainly consists of textile manufactures and food items, largely originating from the agricultural sector where the incidence of uncertainty is quite high and the market is highly competitive. Although, the textile sector constitutes over $65 \%$ of our total exports, its production and exports have attained almost maximum capacity and there is a need to shift the focus to other exportable items. The external shocks taking the form of depressed demand and decreasing price of export products in the international market have made the external sector most vulnerable. As for the destination of Pakistan's exports, about $70 \%$ of exports are directed to 
only 13 countries including the USA, UK, Hong Kong, Germany, Dubai, France, Japan, South Korea and Canada, etc.

The structure of the country's exports calls for a policy shift to diversify exports across different products and also to move towards higher value-added items. The objective of diversification and value addition can be achieved through consistent and well-defined strategies. Due to limited resources, a piece-meal strategy should be adopted to enhance the export base. Initially, there is a need to explore the products in which the country has a comparative advantage and certain low cost measures will help boost the exports, thereby enhancing productivity. In spite of the fact that fruits, vegetables and fish are produced in abundance in Pakistan, the processing industry is not developed. One of the major reasons for Pakistan's poor performance in this field is a lack of storage and canning facilities. Nontraditional agro-based products such as fruits, vegetables, dairy products and fish offer vast scope in augmenting domestic production and exports through crop substitution, the introduction of modern technology for storage, processing and packing, etc. The Export Promotion Bureau should plan cold storage houses at different points in the fruit growing areas to handle farm products for export purposes. These storage houses should also serve as places where training for the packaging of fruits, vegetables and fish for export should be imparted to the exporters.

The textile sector, which is the single largest contributor to the nation's export earnings, has remained concentrated in the relatively low value-added segment of the market, which has retarded the realization of Pakistan's true potential in textile exports. Thus, the need is both to diversify exports across different product categories and also to move to higher value-added textile exports. The slowdown in exports from this sector exerts a dampening effect on the overall export growth. For export diversification through higher value added products, there is a need to upgrade technology, which involves: 1) tailoring the existing technology and processes to specific production requirements; 2) improving processes within the existing technology design; 3) improving the quality of textile products. Information Technology and other hi-tech sectors also require special attention for development according to potential. Due to the economic recession in major industrial economies and enhanced competition, the country may also explore new markets for its products, particularly in the Central Asian Republics, East Asian countries and the African region.

In a changing international environment, Pakistan also needs to diversify exports towards its industrial base. This objective can be achieved by attracting Foreign Development Investment (FDI) selectively in such 
export-oriented industries that correspond to and utilize the dynamic comparative advantage of the country. This will proactively create linkages between domestic firms and Transnational Corporations (TNCs), enabling local firms to tap the technological expertise of TNCs and move into integrated international production systems, as indirect or direct exporters.

\section{Exchange Rate Misalignment and Future Outlook}

In 1994, John Williamson observed that he "cannot see how the Fund could be expected to play a central role in the international monetary system without the analytical capacity to judge whether exchange rates were consistent with satisfactory macro-economic outcomes." Propounding the concept of the Fundamental Equilibrium Exchange Rate (FEER), he defined it as the real effective exchange rate that is consistent with macro-economic balance (which requires the simultaneous attainment of both the internal and external balance).

To make the Real Effective Exchange Rate (REER) based assessments comparable with other variants of equilibrium, the behavior of REER is decomposed into permanent and temporary components and the movements in each is explained in terms of certain determinants. Some studies try to explain the REER appreciation / depreciation through certain identifiable fundamental determinants and any movement in REER that remains unexplained by the fundamentals is ascribed to cyclical / temporary shocks (both internal and external) and interpreted as misalignment. Deviation of the actual REER (based on observed inflation rates) from the equilibrium REER (derived on the basis of fundamental determinants) - the sign of misalignment - is not easy to identify. This is because there could be two types of real exchange rate misalignment. Macroeconomic induced misalignments occur mainly due to inconsistent macro polices (particularly monetary policy). On the other hand, structural misalignment results when changes in real determinants (such as technical progress and shifts in terms of trade) alter the equilibrium REER, but the actual REER does not change (Edwards, 1992). Sachs, Tornell and Velasco (1996) offered two reasons to explain why the market agents also take into account the leading information embodied in the REER.

a) Firstly, the higher the degree of appreciation of the REER and the lower the extent to which tradables respond to REER depreciation, the market receives the signal that a large REER depreciation may be necessary to restore external balance, and accordingly initiates action to ensure a sharp fall in the nominal exchange rate. 
b) Secondly, the more vulnerable an economy is to sudden and large demand compression when demand management measures are instituted to correct the external imbalance, the market perceives that the authorities may prefer depreciation to recession and such market perceptions often trigger the attack. Besides relating to the construction of REER and fixing a benchmark equilibrium level, several operational issues constrain any explicit policy pronouncement on REER.

Misalignment generally refers to deviation of the actual exchange rate from a path that is consistent with the economic fundamentals. Exact identification of the path that could reflect economic fundamentals has, however, proved elusive. The complexity of the issue has spawned an enormous volume of literature, each trying to offer an alternative approximation. For the purpose of identifying misalignment, various determinants of the exchange rate have been used in the literature. The earliest attempt on the subject dates back to 1945 when Ragnar Nurkse defined the equilibrium exchange rate as one that could give rise to an equilibrium in the balance of payments subject to:

1. the absence of any undue restrictions in trade flows,

2. the absence of special incentives to encourage inflow and measures to discourage outflows, and

3. the absence of excessive unemployment.

The recent theoretical and empirical literature on the determinants of the Equilibrium Real Exchange Rate (ERER) in developing countries include Bartolini et al (1994), Edwards (1994), Elbadawi (1994), Guerguil and Kaufman (1998) and Chinn (1998). Edwards (1994) constructed the ERER based on a theoretical model that features a sustainable long-run equilibrium in the nontraded goods and the external sector. The model recognizes the fact that the short-term and long-term determinants of the ERER may differ, and more specifically, only real factors determine the long-run behavior of the real exchange rate whereas both nominal and real factors influence short-run behavior. The model is very similar to Williamson's seminal work (Williamson 1985) except that it is constructed for a small, open economy, which is unable to influence its terms of trade. The construction of the ex-post ERER involves the estimation of the real exchange rate that preserves the internal and the external equilibria. 
Here, we applied the Johansen's full-information maximum-likelihood methodology of cointegrated systems (Johansen 1988) to estimate the ex-post ERER for Pakistan as pinpointing the factors that resulted in the misalignment of the real exchange rate in Pakistan, and could help investigating the aspects of current account sustainability and the appropriateness of exchange rate policies in Pakistan. The estimation procedure is very convenient since it incorporates the cointegration relation to show how the "fundamentals" influence the real exchange rate in the long run and derives the ERER as well as the error correction mechanism to model the short-run adjustment process. The explanatory variables used in the model capture fundamentals such as the fiscal stance, degree of economic openness, international terms of trade, and net capital flows.

The current study uses Engle Granger cointegration technique to estimate the ERER, based on various macroeconomic fundamentals suggested in the economic literature.

\section{Empirical Framework}

The methodology adopted in this paper has earlier been used by Hyder, Zulfiqar and Adil Mahboob (2006). The study has updated the estimates of their study and made forecasts ${ }^{41}$ of misalignment upto 2010. The paper estimates the degree of real exchange rate misalignment based on the model developed by Edwards (1988, 1989, 1994), Elbadawi (1994), and Montiel (1997). The reduced form REER equation is given as follows:

\section{lreer $=f($ ltrop, ltot, lgovc, lrigdp, lremg, capinf, tfpd/t $)$}
$(-) \quad(+/-)(+/-)$
$(-)$
$(+)$
$(-)$
$(+)$

The variables included in the analysis are: the real effective exchange rate index (reer), trade openness (trop), terms of trade (tot), real investment to GDP ratio (rigdp), government consumption as \% of GDP (govc), workers' remittances as \% of GDP (remg), long-term capital to gross domestic product (capinf), and total factor productivity differentials (tfpd) or time trend $(t)$ representing the Harrod-Balassa Samuelson effect. All variables, except capinf and tfpd, are expressed in natural logs. The signs for each fundamental variable in determining the behavior of REER are explained below:

\footnotetext{
41 The forecasts are made under the assumption of the prevalence of a static environment in Pakistan which is likely to remain unchanged up to 2010 and we do not foresee the reversal of significant changes in the external economic front of the Pakistani economy during the period.
} 
- Trade openness depreciates REER because trade liberalization and trade opening makes future consumption of importables very cheap which in turn makes consumers substitute non-tradable for tradable goods.

- The impact of terms of trade on REER is ambiguous and can take either sign depending on the substitution and income effects.

- The impact of government consumption on REER depends not only on the government inter-temporal budget constraints but also on the composition of government consumption. If government consumption contains a larger share of tradable goods, then the increase in government consumption will worsen the current account, and thus lead to a depreciation of REER.

- The sign of rigdp would be negative as the rise in rigdp means higher spending on tradables (imported machinery and raw materials).

- The sign of workers' remittances to GDP ratio on the real exchange rate is positive which reflects that the rise in workers' remittances to GDP ratio, remg, leads to appreciation of the real exchange rate.

- The impact of net capital inflows on REER depends on the magnitude of capital flows. The capital inflows over and above the current account deficit will lead to appreciation of the REER while the capital inflows matching or lower than the current account result in the depreciation of the REER.

- The inclusion of the tfpd or time trend $(t)$ in the REER equation represents the well-known Balassa-Samuelson effect, which contends that productivity improvements will be generally concentrated in the tradable sector and thus lead to an appreciation of the REER.

The Engle-Granger two-step cointegration approach has been used to estimate a single equation REER model for Pakistan. The coefficients from the estimated models and sustainable values of the economic fundamentals are then used to compute the ERER, while the misalignments of the exchange rate are computed by taking the \%age deviations of the actual REER from the ERER. Annual data from Fiscal Year 1978 to Fiscal Year 2006 have been used. The IMF trade-weighted REER index has been used for Pakistan while the rest of the data are taken from the SBP's 
Statistical Bulletin, Economic Survey, and Economic Report of the President on the US economy for the year 2006.

\section{Results Interpretation}

Firstly, the time series properties of data have been checked by testing the stationarity of the fundamental variables. The augmented Dickey-Fuller (ADF) criterion has been applied for unit root and the results of the $\mathrm{ADF}$ test suggest that all the variables are integrated of order one, i.e. I(1), which fulfills the criteria for estimating any long run relations.

The Ordinary Least Square (OLS) has been applied for the estimation of the results. The results are quite encouraging as coefficients and signs in all regressions except rigdp coincide with the earlier empirical studies. In the regression equation, five macroeconomic fundamentals [trade openness (trop), current government consumption to GDP ratio (govc), net capital inflows as \% of GDP, real investment to real GDP ratio (rigdp), and total factor productivity differential (tfpd)] determine the REER. Trop, and the increase in govc and capinf caused depreciation in the REER while an increase in rigdp leads to appreciation of the REER. The improvement in tfpd leads to REER appreciation. The coefficient of $\mathrm{tfpd}$ is small in all three regressions, which is in line with the recent empirical work. In Pakistan's case, workers' remittances are an important source of foreign exchange earnings and finance a large portion of trade and services deficits in the current account balance.

Workers' remittances turn out to be significant and have a positive sign, which reflects that the increase in the remittance inflows cause appreciation of the real exchange rate. Furthermore, the inclusion of the relevant variable, remg, positively affects the overall performance of the regression and causes tot (an important macroeconomic fundamental) to significantly explain the real exchange rate. The positive sign of tot shows that the improvement of tot leads to appreciation of the real exchange rate. However, rigap becomes insignificant with the inclusion of remg and the Wald Test supports the exclusion of rigdp.

The residuals generated from these regressions are tested for unit root to establish a long-run cointegrating relationship. These residuals are stationary, as reflected by the results of the unit root test reported, confirming that the above regression is showing a long-run cointegrating relationship between the REER and economic fundamentals. 


$$
\begin{aligned}
& \text { LRERR }=7.7-0.61 * \text { LTROP }-0.94 * \text { LGOVC + 0.17* LREMG- } \\
& \text { (8.71) (-4.63) (-7.61) }
\end{aligned}
$$

$\mathbf{R}^{2}=\mathbf{0 . 9 6}$

Adj $R^{2}=0.94$

S.E Regression $=0.07$

D.W Statistics $=1.60$

Following are the major results of the regression:

- As trade openness increases by one \%age point of GDP, this leads to real depreciation of $0.61 \%$ of the Pak rupee against the basket of currencies

- An improvement in terms of trade by one percent causes $0.34 \%$ real appreciation of the Pak rupee vis-à-vis the basket of currencies.

- An increase in government expenditure of one percentage point of GDP is associated with $0.94 \%$ real of depreciation of the Pak rupee against the basket of currencies.

- An increase in net capital inflows of one percentage point of GDP causes $0.03 \%$ real depreciation of the REER.

- An increase in workers' remittances of one percentage point of GDP leads to a $0.17 \%$ real appreciation of the Pak rupee against the basket of currencies.

- A one unit reduction in total factor productivity differential relative to trading partners (i.e. US) causes a $0.03 \%$ real appreciation of the Pak rupee against the basket of currencies.

The estimated regressions also satisfied the diagnostic tests. 


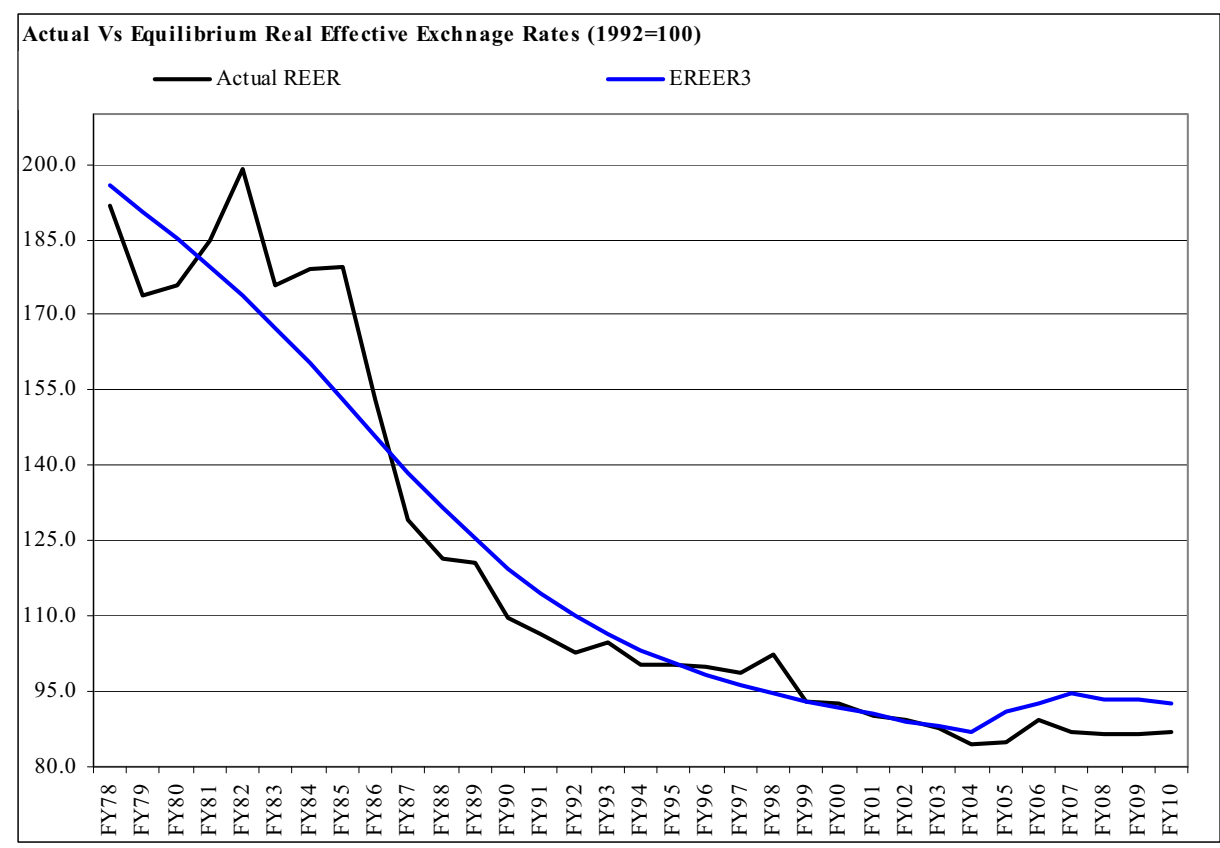

The above long-term relationships can be used to compute the ERERs by evaluating these coefficients at sustainable values of macroeconomic fundamentals. The rationale of using sustainable economic fundamentals is to eliminate short run fluctuations in the explanatory variables and only use long-term equilibrium values of the variables. The Hodrick-Prescott (HP) filter is used to remove the short-term variations from the explanatory variables.

The Figure (above) presents the actual REER and the ERER derived by evaluating the coefficients at the HP filter series of economic fundamentals. The estimated ERER reflects a divergence in both directions from the actual REER in the first part of the sample while the behavior of the actual REER remained close in the latter part of the sample. More specifically, the rupee remained overvalued from 1978 to 1980 relative to the ERER due to a lower price differential and real depreciation of the US dollar against the major currencies. During the period 1981-86, the trend of the actual REER and ERER reveals that the rupee remained undervalued due to the real appreciation of the US dollar against hard currencies. This figure also reflects that the actual REER appears to have been close to its estimated equilibrium REER during the last five years. However, the spread between the forecasts of the REER and ERER appears to have widened during the period up to 2010 mainly on account of real appreciation of the Pak rupee against trading partners and competitors currencies. 
Short-term dynamics of the REER are examined through the estimation of error correction models (ECMs) which show that some of the long-term fundamentals such as trop, capinf, and govc are statistically significant and affect the short-run dynamics of the real exchange rate in the same direction as the variables did in the case of the long run. The estimated regressions also satisfied the post-diagnostic tests such as of no autocorrelation, homoskedasticity, normality of the residuals and stability of parameters.

As described in the economic literature, macroeconomics policies such as the exchange rate policy, fiscal policy and monetary policy may impact the REER in the short run. We investigated the impact of macroeconomic polices and found that excess domestic credit was insignificant while a rise in fiscal deficit as a percentage of GDP and depreciation of the nominal exchange rate (ndev) led to depreciation of the REER in the short run. Monetary policy is statistically insignificant in all the short-run regressions which may reinforce the established view that monetary policy in Pakistan was subservient to fiscal policy. Since monetary policy remained subservient to fiscal policy due to the heavy reliance of the government on financing the fiscal deficit from the banking system, the direct impact of monetary policy in the short term is statistically insignificant. The impact of net devaluation on the ERER turned out to be negative as expected which indicates that nominal devaluation/depreciation of the Pak Rupee against the US \$ depreciates the REER. As the coefficient of the error correction term is negative and has absolute values smaller than one, this not only indicates the stability in the long-term ERER but also reflects the gradual convergence of the exchange rate towards long-run equilibrium. 
We have also derived a misalignment of the exchange rate which is percentage deviations of the actual REER from its equilibrium level. The misalignment is based on the model of the ERER. Negative and positive deviations reflect real appreciation/ depreciation of the actual REER from its equilibrium level.

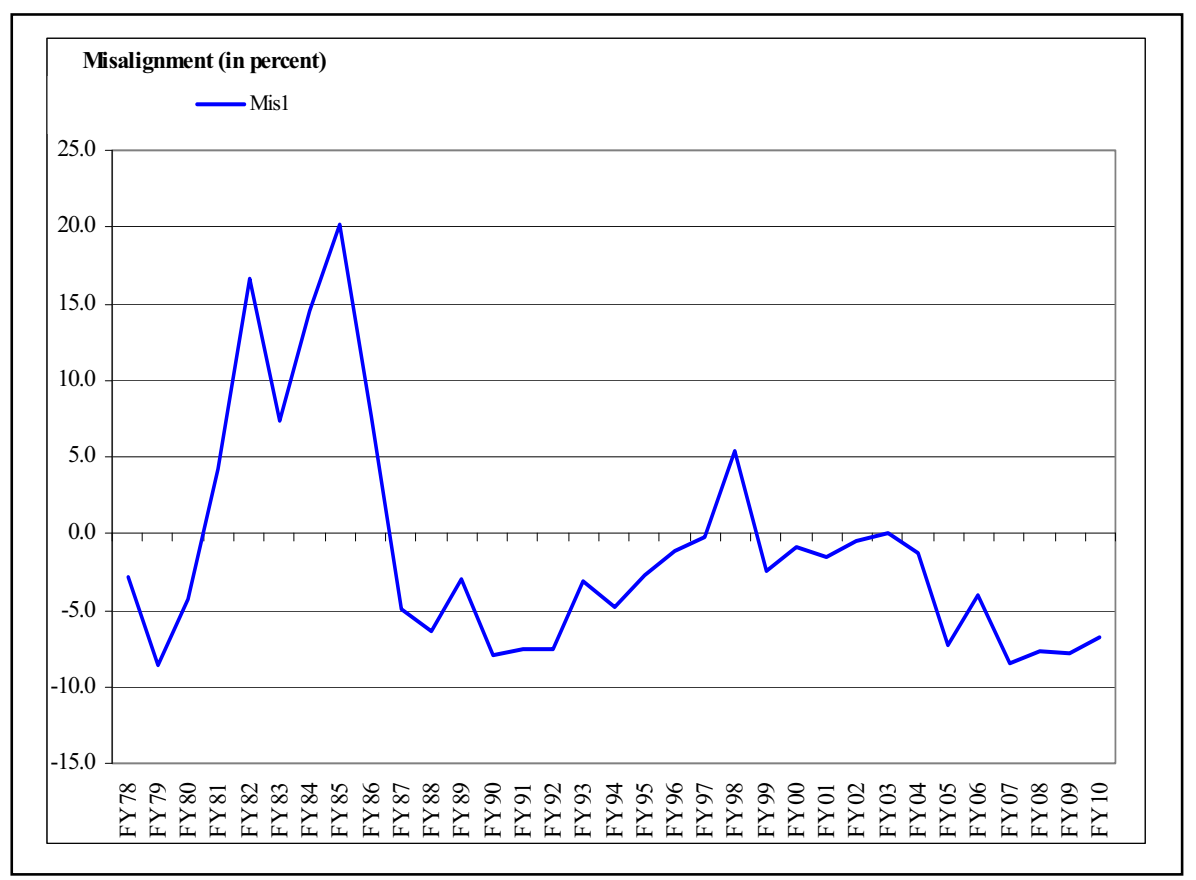

The exchange rate misalignment ranged between $-12.1 \%$ to $25.2 \%$ with zero reversion mean during the year 1978 and 2006. Furthermore, the actual REER in 2006 reflects an appreciation of the REER relative to the ERER. This suggests that the current exchange rate is away from the ERER.

These results yield the following important policy implications for exchange rate policy in Pakistan:

a) ERER is not fixed and is subject to variability as a result of changes in economic fundamentals.

b) Fiscal policy is crucial to exchange rate stability in Pakistan. 
c) The appreciation of the actual REER due to higher price differentials relative to the ERER would lead to exchange rate misalignment.

d) A flexible exchange rate regime responds better in case of real shocks more than other exchange rate regimes. This suggests that the SBP should continue with its current stance of a flexible exchange rate regime and intervene in the interbank market only to smooth unwarranted movements in the exchange rate by keeping in view the ERER and exchange rate misalignment.

To strengthen the viewpoint on exchange rate policy, bi-lateral REER and ERRER has been computed for Yen and Pound Sterling. Both the estimates of ERRER exhibit a completely different picture. The bi-1ateral REER and ERRER and computed misalignment against both the currencies is given in the Appendix.

\section{Where do we go from here?}

1. There has to be identification of and emphasis on the indicators of fundamental equilibrium in the medium term.

2. Policy has to be a more flexible exchange rate to maintain a competitive position in the world market.

3. Policy measures should be identified and if needed, should be introduced immediately to correct any actual or even potential misalignments of the exchange rate.

\section{Policies and Ground Realities}

Apart from a theoretical approach there is a need for greater (and more intensive) coordination among the stakeholders: the SBP and the government, the latter Comprising Finance, Commence, Export Promotion Bureau, Board of Investment and Planning Commission.

Constraining policy hurdles should be removed at the macro and micro level:

- Export industries

- Meeting the requirements of SMEs (fisheries, no bank credit, fishers, do not have any collateral) - the case of tiles. 
- Availability of specific facilities at the Federal, Provincial and Local level. There is a need for improvement in the quality of imports: all those factors which are related to productivity. It is not too early to talk of a knowledge based economy - The role model is Singapore's medium and long term issues.

- The SBP should restrict its role to financial flows and price stability: there should be adequate credit facilities to make full use of the export potential.

- The government should provide incentives to help maintain competitiveness.

- Diversification of exports.

Concentration of exports in commodities: textiles, carpets, leather products, sports goods, surgical instruments, rice etc. There is a need for diversification towards services including I.T., dairy products, cottage industry products, plants and machinery and jewelry.

We must also expand inter-regional trade with India, Bangladesh, Sri Lanka, and China. With over $25 \%$ of our exports going to the U.S.A. we have become extremely vulnerable. Any sanction could spell disaster for us.

\section{Concluding Remarks}

1. Information about the causes of fluctuations in the real exchange rate is important for central banks, as some fluctuations may require immediate corrective actions by them while others may not require this. It is essential to know what kind of movements in the real exchange rate signal a loss in the external competitiveness of the economy. If appreciation of the real exchange rate is due to an improvement in the "fundamentals" such as an increase in the rate of productivity growth in the tradable goods sector of an economy, the central banks in this case need not take any corrective action. However, if the real exchange rate deviates significantly from its equilibrium level, also known as a "misalignment", the competitive stance of the Pak economy would be jeopardized and require immediate "corrective action" by the SBP.

2. The real exchange rate responds to real as well as nominal (monetary) variables. At any given moment, the real exchange rate depends on economic fundamentals (e.g. tariffs, international prices, 
real interest rates, etc.) and aggregate macroeconomic pressures, generated by an excess supply of money or a fiscal deficit or both.

3. In order to achieve sustainable macroeconomic equilibrium, monetary and fiscal policies must be consistent with the chosen nominal exchange rate regime. Further, the misalignments in the real exchange rate can be used as a guideline for policy interventions by the SBP.

4. Pakistan's Balance of Payments (BoP) is characterized by persistent large external financing needs with weak economic activity in the country. This has cast doubt on the possibility of exchange rate misalignment in Pakistan.

5. The CPI-based REER index suggests that the Pak. rupee has been depreciating over the period of the study. However, the rate of real depreciation of the Pak rupee was lower than the actual need which is evident by the widening of Pakistan's trade deficit. Moreover, Pakistan's export base remained stagnant and did show significant diversification in the last decades, which is reflected in a constant export market share and deteriorating trade balances.

6. There are some signs of external financial vulnerability and the country's real exchange rate appears to be somewhat overvalued, a situation that could be best addressed through increased fiscal discipline.

7. The BOP statistics show that despite continued devaluation, the Current Account Deficit (CAD) in Pakistan has deteriorated. This does not necessarily mean that the exchange rate polices do not work. The exchange rate policy in Pakistan failed due to a number of factors. The most important reason is that devaluation was accompanied by poor monetary management. In particular a continued growth in money supply resulted in a high inflation rate which neutralized the favorable affects of devaluation on the real exchange rate and Pakistan could not achieve any competitive advantage from devaluation. What really matters is to improve the BOP position through adjustment in the real exchange rate. To influence the real exchange rate through devaluation, Pakistan should have adopted a tight monetary policy. Thus, except for the intervention in the foreign exchange market the State Bank of Pakistan should have held tight control on money supply. 
8. In a changing international environment, Pakistan also needs to diversify exports towards its industrial base. This objective can be achieved by attracting FDI selectively into such export-oriented industries that correspond to and utilize the dynamic comparative advantages of the country. This will proactively create linkages between domestic firms and Transnational Corporations (TNCs), enabling local firms to tap the technological expertise of TNCs and move into integrated international production systems, as indirect or direct exporters.

9. The structure of the country's exports suggests the need for a policy shift, to diversify exports across different products and also to move towards higher value-added items. The objective of diversification and value addition can be achieved through consistent and well-defined strategies. Due to limited resources, a piece-meal strategy should be adopted to enhance the exports base. Initially, there is a need to explore the products in which the country has a comparative advantage and certain low cost measures will help boost exports, thereby enhancing productivity. In spite of the fact that fruits, vegetables and fish are produced in abundance in Pakistan, the processing industry is not developed. One of the major reasons for Pakistan's poor performance in this field is lack of a storage and canning facility. Non-traditional agro-based products like fruits, vegetables, dairy products and fish offer vast scope to augment domestic production and exports through crop substitution, the introduction of modern technology for storage, processing and packing, etc. The Trade Development Authority of Pakistan (TDAP), formerly the Export Promotion Bureau, should plan cold storage houses at different points in the fruit growing areas to handle farm products for export purposes. These storage houses should also serve as places where training for the packaging of fruits, vegetables and fish for export should be imparted to the exporters.

10. The variables such as trade openness, government consumption and capital inflows lead to depreciation of the REER index, while workers' remittances, terms of trade, and total factor productivity vis-à-vis trading partners lead to an appreciation of the REER index. 


\section{References}

Arslaner, F. and G. Erlat, 1997, "Measuring Annual Real Exchange Rate Series for Turkey", Yapi Kredi Economic Review Vol. 8, No. 2, pp. $35-61$.

Black, S., 1994, "On the Concept and Usefulness of the Equilibrium Rate of Exchange”, in J. Williamson (ed.), Estimating Equilibrium Exchange Rates, Institute for International Economics, Washington, DC.

Bartolini, L., P. Clark, T. Bayoumi, and S. Symansky, 1994, "Exchange Rates and Economic Fundamentals: A Framework for Analysis", IMF Occasional Paper No. 115.

Chinn, M., 1998, "Before the Fall: Were East Asian Currencies Overvalued?" NBER Working Paper No. 6491.

Economic Report of the President, 1999, "International Capital Flows, Their Causes, and the Risk of Financial Crisis," Chapter 6, United States Government Printing Office, Washington, 1999.

Edwards, S., 1994, "Real and Monetary Determinants of Real Exchange Rate Behavior: Theory and Evidence from Developing Countries", in Estimating Equilibrium Exchange Rates, ed. by J. Williamson, Institute for International Economics, Washington, DC.

Elbadawi, I., 1994, "Estimating Long-Run Equilibrium Real Exchange Rates”, in J. Williamson (ed.), Estimating Equilibrium Exchange Rates, Institute for International Economics, Washington, DC.

Feyzioglu, T., 1997, "Estimating the Equilibrium Exchange Rate: An Application to Finland", IMF Working Paper No: 97/109.

Guerguil, M. and M. Kaufman, 1998, "Competitiveness and the Evolution of the Real Exchange Rate in Chile”, IMF Working Paper No. 98/58.

Hyder, Zulfiqar and Adil Mahboob, 2006, "Equilibrium Real Effective Exchange Rate and Exchange Rate Misalignment in Pakistan”, SBP Working Paper Series, 2006.

Johansen, S., 1988, "Statistical Analysis of Cointegration Vectors", Journal of Economic Dynamics and Control, No. 12, pp. 231-254. 
Johansen, S., 1991, "Estimation and Hypothesis Testing of Cointegration Vectors in Gaussian Vector Autoregressive Models”, Econometrica, Vol. 52, pp. 389-402.

Kwiatkowski, D., P. Phillips, P. Schmidt, and Y. Shin, 1992, "Testing the Null Hypothesis of Stationarity Against the Alternative of a Unit Root: How Sure are We that Economic Time Series have a Unit Root?” Journal of Econometrics Vo1. 44, pp. 159-178.

Rogoff, K., 1996, "The Purchasing Power Parity Puzzle”, Journal of Economic Literature 34, no. 2, pp. 647-668.

Saygili, M., G. Sahinbeyoglu and P. Ozbay, 1998, "Competitiveness Indicators and the Equilibrium Real Exchange Rate Dynamics in Turkey", in Macroeconomic Analysis of Turkey: Essays on Current Issues, Research Department, The Central Bank of The Republic of Turkey.

Williamson, J., 1985, “The Exchange Rate System" Policy Analyses in International Economics 5, Institute of International Economics, Washington, D.C. 


\section{$\underline{\text { Appendix }}$}

\section{Bilateral Misalignment}

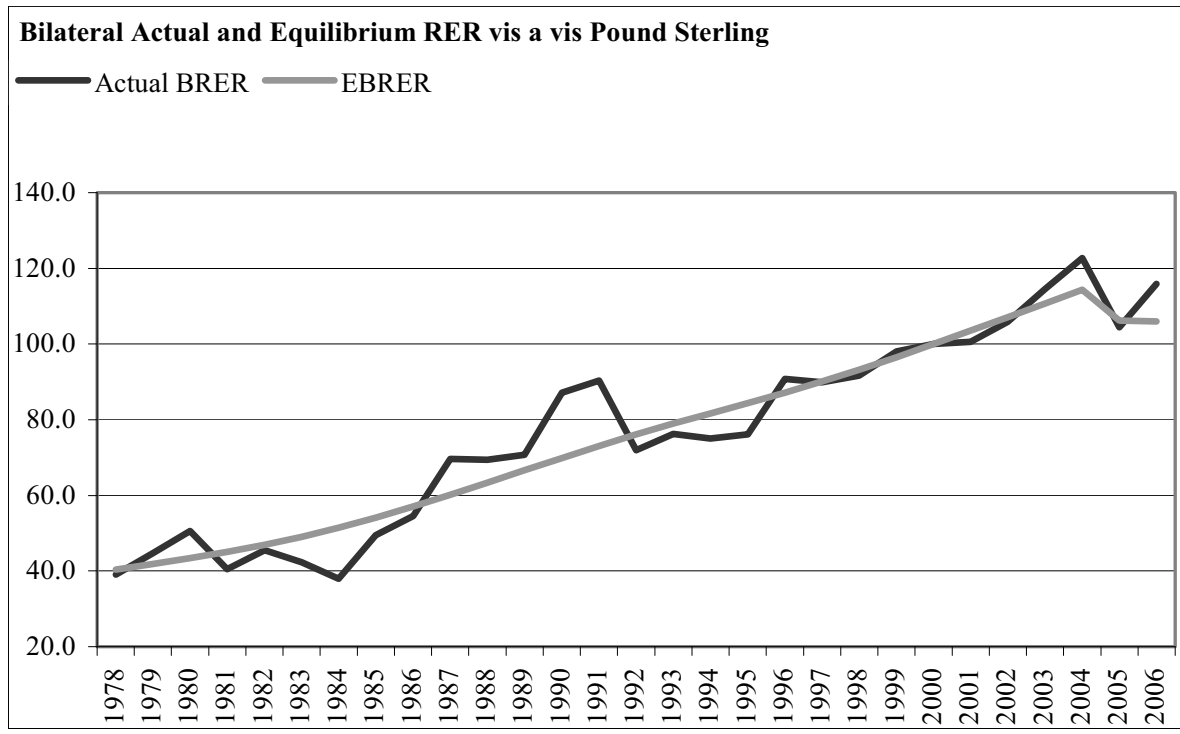

Misalignment (in percent)

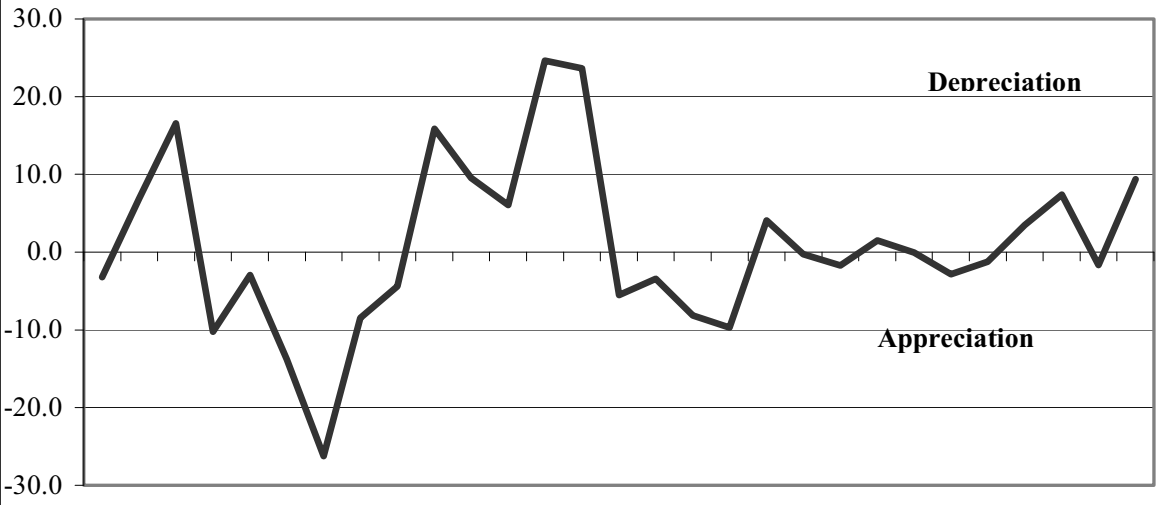

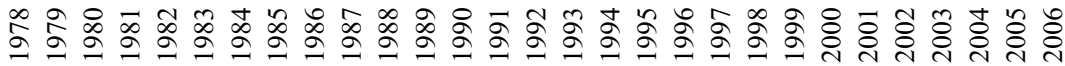



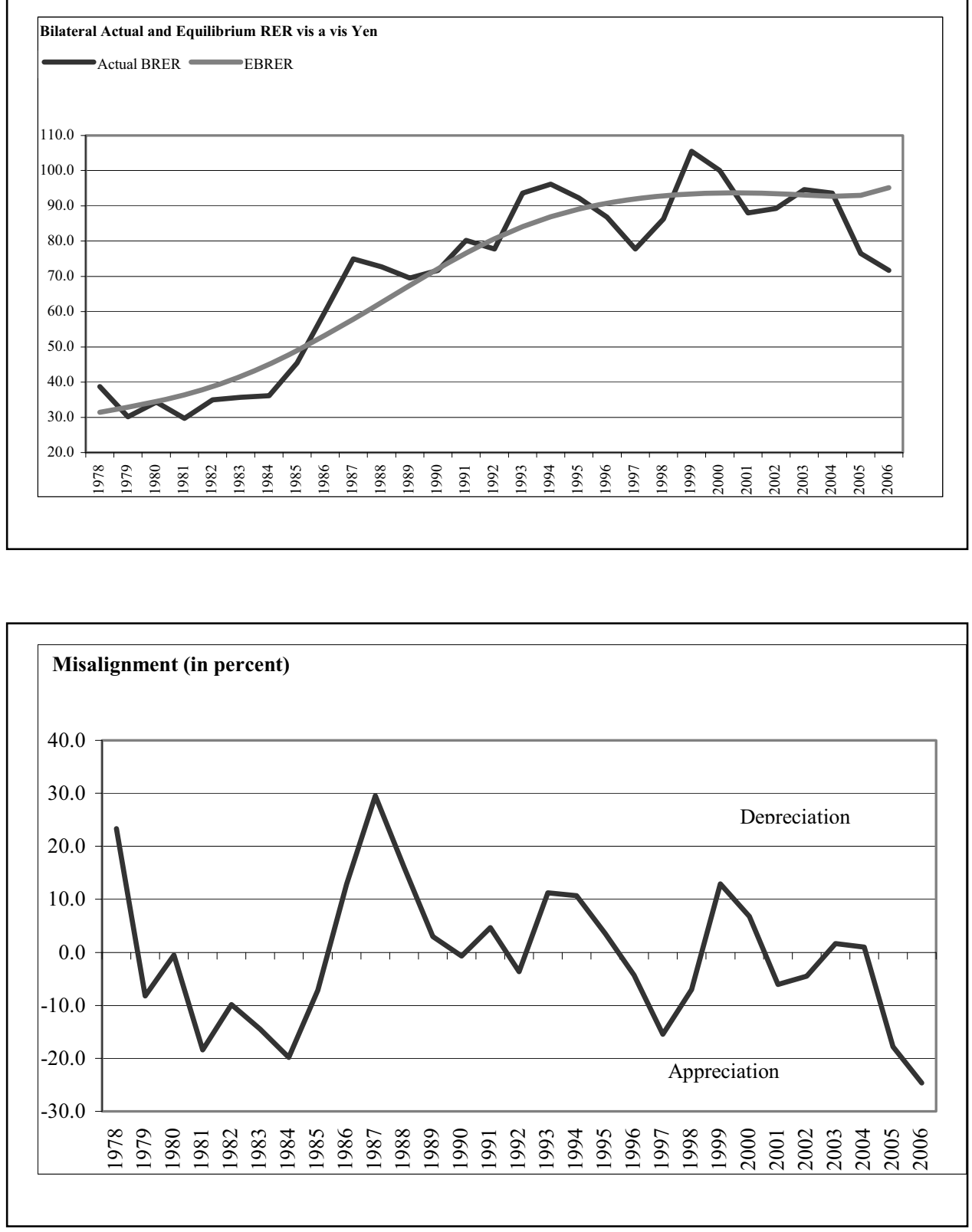